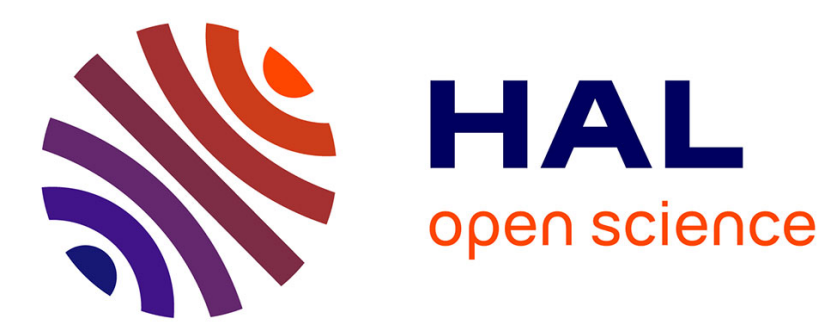

\title{
Influenza B meningoencephalitis
}

\author{
Emilie Piet, Pierre Tattevin, Alexandra Mailles, Jean-Paul Stahl
}

\section{To cite this version:}

Emilie Piet, Pierre Tattevin, Alexandra Mailles, Jean-Paul Stahl. Influenza B meningoencephalitis. Médecine et Maladies Infectieuses, 2017, 47 (6), pp.435-436. 10.1016/j.medmal.2017.06.001 . hal01621639

\section{HAL Id: hal-01621639 \\ https://hal-univ-rennes1.archives-ouvertes.fr/hal-01621639}

Submitted on 23 Oct 2017

HAL is a multi-disciplinary open access archive for the deposit and dissemination of scientific research documents, whether they are published or not. The documents may come from teaching and research institutions in France or abroad, or from public or private research centers.
L'archive ouverte pluridisciplinaire HAL, est destinée au dépôt et à la diffusion de documents scientifiques de niveau recherche, publiés ou non, émanant des établissements d'enseignement et de recherche français ou étrangers, des laboratoires publics ou privés. 
Lettre à la Rédaction

\section{Influenza B meningoencephalitis}

\section{Méningoencéphalite à influenza B}

E. Piet ${ }^{\mathrm{a}}$

P. Tattevin ${ }^{\mathrm{b}, *}$

A. Mailles ${ }^{\mathrm{c}}$

J.-P. Stahl ${ }^{d}$

${ }^{a}$ Infectious diseases unit, Annecy Genevois Hospital, Annecy, France

${ }^{b}$ Department of Infectious Diseases and Intensive Care Unit, Pontchaillou University Hospital, Rennes, France

${ }^{c}$ French National Public Health Agency, Saint-Maurice, France

${ }^{d}$ Infectious Diseases and Tropical Medicine, University Hospital, Grenoble, France

* Auteur correspondant

Adresses e-mail: epiet@ch-annecygenevois.fr (E. Piet); pierre.tattevin@chu-rennes.fr (P.

Tattevin); Alexandra.mailles@santepubliquefrance.fr (A. Mailles); JPStahl@chugrenoble.fr (J.-P. Stahl) 


\section{Introduction}

Encephalitis is a rare complication of influenza, mostly reported with influenza A, and in children. We report two cases of influenza B meningoencephalitis in adults enrolled in the French encephalitis cohort study (ENCEIF) during the 2015-2016 seasonal influenza outbreak.

\section{Case reports}

A 72 year-old female was admitted with fever and seizures, after a three-day course of influenza-like illness (ILI). She had a medical history of chronic obstructive pulmonary disease. She was not immunized against influenza. On admission, body temperature was $38.3^{\circ} \mathrm{C}$, and neurological examination was normal. Contrast-enhanced brain MRI was unremarkable. Disseminated abnormalities suggesting encephalitis were observed on EEG. Cerebrospinal fluid (CSF) analysis yielded: white blood cells, 20/ $\mathrm{mm}^{3}$ (60\% lymphocytes), protein $0.6 \mathrm{~g} / \mathrm{L}$, glucose $0.7 \mathrm{~g} / \mathrm{L}$, no micro-organism observed after Gram staining, and negative PCR for HSV, VZV, and enterovirus. CSF and blood cultures were sterile. PCR carried out on a nasopharyngeal swab was positive for influenza B. She was initially treated with i.v. aciclovir, $10 \mathrm{mg} / \mathrm{kg} / 8 \mathrm{~h}$, and oral oseltamivir, $150 \mathrm{mg}$ b.i.d. One day after admission, she became confused and had a relapse of seizures. A second lumbar puncture was performed four days after neurological symptoms onset, with negative PCR for HSV, VZV, EBV, CMV, HHV-6, adenovirus, enterovirus, Neisseria meningitidis, Streptococcus pneumoniae, Haemophilus influenzae, Listeria monocytogenes, influenza A and B. Aciclovir was stopped, and oseltamivir was continued for a total duration of 5 days. All symptoms resolved within ten days.

A 49 year-old male was admitted for aphasia and confusion, after one week of ILI. He was not immunized against influenza. No abnormality was observed with brain CT scan and 
MRI. CSF analyses were as follow: 40 white blood cells $/ \mathrm{mm}^{3}$ (100\% lymphocytes), protein 1 $\mathrm{g} / \mathrm{L}$, glucose $4.2 \mathrm{mmol} / \mathrm{L}$, no micro-organism observed after Gram staining, and negative PCR for HSV and enterovirus. Blood and CSF culture were sterile. PCR carried out on a nasopharyngal swab was positive for influenza B. At reception of this result, the patient was treated for 5 days with oseltamivir, $150 \mathrm{mg}$ b.i.d. and all symptoms had resolved by day 3 of treatment.

\section{Discussion}

Neurological complications of influenza are rare, with an estimated incidence at 1.2 / 100,000 symptomatic flu presentations during the A(H1N1) 2009 pandemic. A two-year nationwide surveillance study performed through the British adult and pediatric neurological surveillance units identified 25 cases of neurological diseases with documented influenza, of which only five $(20 \%)$ occurred in adults, four $(15 \%)$ were due to influenza B, and three (12\%) had CSF features of meningitis. The four adult cases were related to influenza A, and none had meningoencephalitis: one had a Guillain-Barré syndrome, one had an acute hemorrhagic leukoencephalopathy, and two had an acute benign encephalopathy with movement disorder, but normal CSF [1]. To the best of our knowledge, only two cases of influenza B encephalitis have been reported in adults thus far, but CSF findings did not support a diagnosis of meningitis [2]. Of the 254 patients with encephalitis enrolled in the 2007 prospective cohort study in France, only one case was associated with influenza $(<1 \%$ of documented cases), and this was influenza A [3]. Influenza was associated with $4 \%$ of documented infectious encephalitis in England in 2007-2008 [4].

The two cases we report are similar to previously reported cases of influenza encephalitis. They occurred in unvaccinated patients, and neurological symptoms appeared after a few days of ILI. Influenza was only documented through respiratory samples: indeed, PCR tests for 
influenza in CSF are usually negative, even in cases of severe influenza encephalitis [1,5]. With the exception of acute necrotizing encephalitis, a rare complication of influenza reported in children from Asia, most cases of influenza encephalitis resolved within a few days. Both patients reported here recovered fully. They received a five-day course of high-dose oseltamivir at the reception of PCR results, although the benefit of this drug in influenza encephalitis has not been demonstrated.

The 2015-2016 influenza outbreak was quite unusual in France. It started later than usual, was of longer duration (11 weeks), and was due to an unexpected strain: influenza B/Victoria, which was not included in the seasonal vaccine. This strain was involved in $71 \%$ of documented cases [6].

\section{Conclusion}

We report these unusual observations of influenza B meningoencephalitis in adults for two reasons: i) Their occurrence during this unusual seasonal influenza outbreak suggests that the influenza B/Victoria strain may have a specific neurotropism, not reported with influenza B thus far; ii) influenza should not be neglected among the list of pathogens that may be involved in encephalitis, as this diagnosis has consequences in terms of infection control, and specific treatment. In conclusion, PCR tests for influenza in nasopharyngeal swabs should be performed in patients who present with encephalitis after a few days of ILI during the influenza season.

\section{Conflict of interest}

There is no conflict of interest. 


\section{Acknowledgement}

No funding was received for this work

\section{References}

(1) Goenka A, Michael BD, Ledger E, Hart IJ, Absoud M, Chow G, et al. Neurological manifestations of influenza infection in children and adults: results of a National British Surveillance Study. Clin Infect Dis 2014;58:775-84.

(2) Ak Ö, Biteker F, Cag Y, Öcal G, Benzonana N, Ciblak MA, et al. Influenza B-associated encephalopathy in two adults. J Infect Chemother 2012;18:961-4.

(3) Mailles A, Stahl JP; Steering Committee and Investigators Group. Infectious Encephalitis in France in 2007: A National Prospective Study. Clin Infect Dis 2009;12:1838-47.

(4) Granerod J, Ambrose HE, Davies NW, Clewley JP, Walsh AL, Morgan D, et al. Aetiology of Encephalitis Study Group. Causes of encephalitis and differences in their clinical presentations in England : a multicenter population-based prospective study. Lancet Infect Dis. 2010;10:835-44.

(5) Akins PT, Belko J, Uyeki TM, Axelrod Y, Lee KK, Silverthorn J. H1N1 Encephalitis with Malignant Edema and Review of Neurologic Complications from Influenza. Neurocrit Care. 2010;13:396-406.

(6) Équipes de surveillance de la grippe. Influenza activity in mainland France, season 20152016. Bull Epidémiol Hebd. 2016; (32-33):558-63. http://invs.santepubliquefrance.fr/beh/2016/32-33/2016 32-33 $1 . \mathrm{html}$ 